\title{
Legislative and executive translation of the right to have access to health care services
}

\author{
MARIUS PIETERSE* \\ Professor of Law, University of the Witwatersrand
}

\section{INTRODUCTION}

The disconnection between the vision of social justice espoused by the 1996 Constitution and the lived experiences of its subjects presents probably the most significant threat to the legitimacy of the South African constitutional order. The justiciable socio-economic rights contained in chapter 2 of the Constitution, which were intended as tools with which to bridge this disconnection, are in danger of becoming its starkest examples. If they are to be of any relevance to the masses they were designed to serve, the constitutional rights of access to adequate housing, food, water, social security, education and health care services require effective and urgent translation from conceptually empty and contested "background norms" into concrete, claimable legal entitlements. ${ }^{1}$

With a number of notable exceptions, the bulk of South African socio-economic rights scholarship to date has focused on the manner in which such translation has materialised, or failed to materialise, through the use of the rights in litigation. Yet it is generally accepted that the judicial process is neither the primary nor necessarily the preferred site for this translation. For reasons of institutional legitimacy, resources, expertise, capacity and clout, the legislative and executive branches of government are typically regarded as being best placed to articulate specific socioeconomic entitlements and to establish the administrative and other processes

\footnotetext{
* A different version of this article was presented at the International Conference on the Realisation of the Rights to Health and Development, held in Hanoi from 26-29 October 2009. The research in the article was made possible by a project grant from the Research Committee of the Faculty of Commerce, Law and Management at the University of the Witwatersrand. Thanks to Paul Wayburne for research assistance and to two anonymous referees for very helpful comments on a previous draft.

${ }^{1}$ Brand D "Introduction to socio-economic rights in the South African Constitution" in Brand D \& Heyns C (eds) Socio-economic Rights in South Africa (2005) 1, 2; 12; Hassim A; Heywood M \& Berger J (eds) Health and Democracy (2007) 265; Pieterse M "Resuscitating socio-economic rights: Constitutional entitlements to health care services" (2006) 22 SAJHR 473, 478; Pieterse M “On 'dialogue', 'translation' and 'voice': A reply to Sandra Liebenberg" in Woolman S \& Bishop M (eds) Constitutional Conversations (2008) 331, 332.
} 
through which these may effectively be claimed.2 Indeed, they are constitutionally mandated to do this, as reflected by the State's obligation under sections 26(2) and $27(2)$ of the Constitution to progressively realise socio-economic rights within its available resources by taking reasonable legislative and other measures.

It is thus understandable that the Constitutional Court's socio-economic rights jurisprudence has thus far focused on endorsing, overseeing and evaluating the effectiveness of legislative and executive attempts at translating socio-economic rights into reality, rather than of itself fleshing out the constitutional guarantees in question. $^{3}$ But has this been adequate in ensuring meaningful legislative and executive translation? More pertinently, is the general faith in legislative and executive translation processes justified?

Without letting courts off the hook entirely, this article takes a closer look at the extent of legislative and executive translation of the right to have access to health care services in terms of section 27 of the Constitution. It questions the widely held view (increasingly echoed by government) that non-enjoyment of this right is due, not so much due to shortcomings in the content of health legislation or policies, but rather to the State's inability (due to constraints posed by logistics, resources and capacity) to properly implement them. ${ }^{4}$ While acknowledging the challenges posed by implementation, the article establishes a link between a number of these challenges and failures of translation. It points to several instances where the current legislative and policy framework pertaining to access to health care services falls short of adequately translating constitutional guarantees, and illustrates how these shortfalls preclude effective enjoyment of the rights in question. By doing this, the article aims to further infuse debates over the manner and extent to which "political" translations of socio-economic rights are subjected to judicial scrutiny.

Section 2 below unpacks this article's understanding of the notion of "translation" and considers features of legislative and executive translation processes that impact on the effectiveness thereof. Thereafter section 3 engages with the current extent of translation of section 27 of the Constitution, identifies failures of translation and interrogates some of the reasons behind these. Section 4 then shifts the focus to judicial evaluations of legislative and executive translation processes and considers the extent to which the Constitutional Court's current approach to socio-economic rights adjudication can identify, and correct, translation failures.

\footnotetext{
2 Pieterse M "Coming to terms with judicial enforcement of socio-economic rights" (2004) 20 SAJHR 383, 387-88 and authorities cited there; Pieterse (2008) (fn 1 above) 334; Viljoen F "National legislation as a source of justiciable socio-economic rights" (2005) 6(3) ESR Review 6, 8.

3 For criticism of the Court's conception of its own role in relation to the translation of socio-economic rights, see Pieterse (2008) (fn 1 above) 342-45.

${ }^{4}$ See, for example, South African Human Rights Commission (SAHRC) Report Public Inquiry: Access to Health Care Services (2008) 6; 55-6.
} 


\section{RIGHTS, NEEDS AND THE NEED FOR EFFECTIVE RIGHTS- TRANSLATION BY LEGISLATURES AND EXECUTIVES}

According to Nancy Fraser, the "politics of need interpretation" involve three interrelated processes. These are, first, a struggle concerning the political validation of need; secondly, a struggle pertaining to the definition or interpretation of such need; and, thirdly, a struggle over its implementation. ${ }^{5}$ In South Africa, where the struggle over political need-validation successfully resulted in the constitutionalisation of justiciable socio-economic rights, we are currently occupied with the second and third of these processes, both of which relate to the translation of politically validated needs into lived reality. ${ }^{6}$

Of course, the fact that the socio-economic rights in the Constitution are justiciable in itself presents an important avenue for this translation. This is because beneficiaries can insist on the satisfaction of their constitutional rights through the judicial process. ${ }^{7}$ Unfortunately, this avenue has proved less effective in South Africa than initially anticipated, due to the Constitutional Court's unwillingness to interpret the socio-economic rights in the Constitution as embodying immediately claimable individual demands. ${ }^{8}$

But direct reliance on constitutional socio-economic rights in litigation is not the only way in which they may be enforced. The constitutional presence of socioeconomic rights mandates the political branches of government to progressively translate them into demandable entitlements. It also provides substantive guidelines for such translation and fortifies translated entitlements against private challenges and against future legislative or executive back-scaling. ${ }^{9}$

But what is meant by "translation"? As Lucy Williams explains, the actualisation of a socio-economic right involves three dimensions. First, a substantive entitlement needs to be legally articulated and defined. Secondly, legal and/or administrative mechanisms must be established through which the entitlement may be claimed or through which wrongful non-delivery of the objects of the entitlement may be challenged. Thirdly, beneficiaries must be aware of their rights as well as of the mechanisms through which to enforce them, and must practically be able to utilise

\footnotetext{
5 Fraser N Unruly Practices: Power, Discourse and Gender in Contemporary Social Theory (1989) 163-64, as cited and discussed in the South African socio-economic rights context by Liebenberg $\mathrm{S}$ "Needs, rights and transformation: Adjudicating social rights" (2006) 17 Stellenbosch LR 5, 15-16.

${ }^{6}$ Liebenberg ibid 16-17.

7 Brand (fn 1 above) 2; Pieterse (2006) (fn 1 above) 477 and authorities cited there.

8 Pieterse ibid 487; 490.

9 Brand (fn 1 above) 13; 15; Viljoen (fn 2 above) 8; Williams LA "Issues and challenges in addressing poverty and legal rights: A comparative United States / South African analysis" (2005) 21 SAJHR 436, 439; 447.
} 
the above mechanisms in order to secure actual enjoyment of the goods or services guaranteed by the entitlement. 10

The first two dimensions identified by Williams constitute what this article understands as "translation" of socio-economic rights, as these work together to create statutory or policy-based individual entitlements "of particular persons to particular things",11 which may be demanded by adhering to established processes. The third dimension mostly implies what is commonly understood as "implementation", in that it requires of subjects to be aware of entitlements and depends on established processes being accessible, workable and responsive to individual demands. But the three dimensions of rights-enjoyment are clearly interrelated, in that successful implementation of a substantive right clearly flows from, and depends upon, its adequate translation.

The respective roles of the legislature and executive in effecting the translation and implementation of socio-economic rights are fairly obvious. The legislature may enact statutory socio-economic rights and prescribe the mechanisms for their enforcement. Alternatively, it may delegate such translation to the executive, by both enabling and requiring of relevant State departments to flesh out the content of entitlements and to establish enforcement processes for them by way of policy. ${ }^{12}$ Where this is the case, the executive has a dual role - as secondary translator of socioeconomic rights as well as the body primarily responsible for their implementation.

Statutory or policy-based socio-economic entitlements tend to be more specific, concrete and easily claimable than the constitutional background norms to which they give effect. ${ }^{13}$ Where they are also justiciable (which is not necessarily always the case), they further prove to be significantly easier to enforce judicially than is the case with constitutional rights. This is because courts are more comfortable, within their own understanding of the separation of powers, to enforce obligations against the political branches that those branches have themselves defined, rather than to both define and enforce obligations, as is sometimes required in relation to less specific constitutional guarantees. ${ }^{14}$ Together with the significant advantages occasioned by the political branches' institutional legitimacy, expertise and resources and with the possibilities for public involvement and effective enforcement that are inherent to legislative and executive processes, these factors appear to justify a strong preference for legislative and executive translation over alternative (judicial or other) translation processes.

10 Williams (ibid) 439. See also Brand (fn 1 above) 13; Liebenberg (fn 5 above) 17; Martin P "Just administrative action: The key to accessing socio-economic rights" (1999) 2(1) ESR Review 9-11; Mubangizi JC "Protection of human rights in South Africa: Public awareness and perceptions" (2004) 29 Journal of Juridical Science 62, 64; Pieterse (2008) (fn 1 above) 334.

11 Brand (fn 1 above) 13.

12 Ibid 14; 16; Viljoen (fn 2 above) 8.

${ }^{13}$ Brand (fn 1 above) 14; Viljoen (fn 2 above) 8-9.

${ }^{14}$ Brand (fn 1 above) 14; 16; 23-4; Pieterse (2006) (fn 1 above) 496; Viljoen (fn 2 above) 8. 
But several factors impact negatively on the quality and effectiveness of legislative or executive translation. Legislatures and executives face constraints of time, capacity and competing priorities, which retard translation and reduce its effectiveness. Moreover, they are prone to interest group capture, do not always perceive or appreciate the needs of their subjects and often lack the political will to define and operationalise obligations that they themselves must heed. ${ }^{15}$ Translation fails where the legislature or executive, for these or other reasons, fail to define socio-economic entitlements or to operationalise them. It is further significantly compromised where statutory or policy-based socio-economic entitlements are under-inclusive, rigidly defined, unduly limited, narrower than the rights to which they give effect, vague, indeterminate, left without appropriate institutional backing or insufficiently entrenched.16

Limited enjoyment of socio-economic rights may accordingly be the result of absent or inadequate translation just as often as it may be ascribable to inadequate implementation of adequately translated entitlements. Importantly, translation failures more often than not have little to do with the resource or capacity constraints that are often offered as explanation for poor implementation. ${ }^{17}$ In what follows, I argue that many of the shortfalls in current enjoyment of constitutional health rights are ascribable to such failures of translation.

\section{THE EXTENT OF LEGISLATIVE AND EXECUTIVE TRANSLATION OF THE RIGHT TO HAVE ACCESS TO HEALTH CARE SERVICES}

A fairly impressive number of legislative enactments aimed at giving effect to the constitutional right of access to health care services have been passed since the coming into operation of the 1996 Constitution. To a greater or lesser extent, all of these have contributed to the translation of the right, either by clarifying individual entitlements and corresponding public or private health sector obligations, or by creating a regulatory framework which enables further translation. Yet, as will be shown, significant translation breakdowns continue to hinder access to health care services, especially by poor and vulnerable persons in the public health system.

This section of the article will first provide an overview of the significant translation of section 27(1)(a) of the Constitution that has been achieved, in relation to members of medical aid schemes, by the Medical Schemes Act 131 of 1998 and its

15 For further discussion, see Dixon $\mathrm{R}$ "Creating dialogue about socio-economic rights: Strong-form versus weak-form judicial review revisited" (2007) 5(3) Int. J of Constitutional Law 391, 402-04; 414; Liebenberg S "Socio-economic rights: revisiting the reasonableness review / minimum core debate" in Woolman S \& Bishop M (eds) Constitutional Conversations (2008) 303, 312; Pieterse (fn 2 above) 387; Pieterse (2008) (fn 1 above) 334-35.

16 See Brand (fn 1 above) 15; Pieterse (2006) (fn 1 above) 497; Pieterse (2008) (fn 1 above) 334-35; Williams (fn 9 above) 455.

17 Dixon (fn 15 above) 403. 
pursuant regulations. By way of contrast, it then considers the far more tentative (although not insignificant) translation of the right for the broader population, in terms of the National Health Act 61 of 2003. After providing a general description of the extent of enforceable entitlements to health care created and operationalised by the Act and its accompanying regulations and policy documents, I consider the extent to which translation in terms of these instruments has been successful in relation to three distinct topics - access to emergency medical treatment, access to termination of pregnancy services and access to health care services by non-citizens. This is followed by a brief analysis of the various breakdowns in translation identified in the course of this overview.

\subsection{Translation for the upper classes: regulation of medical schemes and access to health services in the private sector}

One of the most successful instances of legislative and executive translation of the right to have access to health care services, both directly and indirectly (by way of the creation of a translation-enabling regulatory framework), relates to the regulation of the medical insurance industry. The Medical Schemes Act 131 of 1998 and its accompanying regulations have significantly empowered persons in their efforts to become members of medical schemes and have enabled members to insist on certain forms of medical treatment for themselves and their dependants.

Not only does the Act contain the most comprehensive definition of the concept "health services" to be found in any South African statute or policy document, 18 it entitles all persons who are able to afford membership of medical schemes to be admitted as members regardless of their "race, gender, marital status, ethnic or social origin, sexual orientation, pregnancy, disability [or] state of health"19 and prohibits medical schemes from taking into account the members or their dependants' current state of health, or the frequency with which they require health care, when determining their membership contributions. ${ }^{20}$

\footnotetext{
18 Section 1 of Act 131 of 1998 defines "relevant health service" as "any health care treatment of any person by a person registered in terms of any law, which treatment has as its object - (a) the physical or mental examination of that person; (b) the diagnosis, treatment or prevention of any physical or mental defect, illness or deficiency; (c) the giving of advice in relation to any such defect, illness or deficiency; (d) the giving of advice in relation to, or treatment of, any condition arising out of a pregnancy, including the termination thereof; (e) the prescribing or supplying of any medicine, appliance or apparatus in relation to any such defect, illness or deficiency or a pregnancy, including the termination thereof; or (f) nursing or midwifery, and includes an ambulance service, and the supply of accommodation in an institution established or registered in terms of any law as a hospital, maternity home, nursing home or similar institution where nursing is practised or any other institution where surgical or other medical activities are performed, and such accommodation is necessitated by any physical or mental defect, illness or deficiency or by a pregnancy".

${ }^{19}$ Section 24(2)(e) of Act 131 of 1998.

${ }^{20}$ Section 29(1)(n).
} 
The Act further entitles members to post-retirement continuation of membership of medical schemes and also enables their dependants to remain beneficiaries of schemes after the members' death. ${ }^{21}$ Crucially, when read with its accompanying regulations, the Act enables members to insist that their schemes fully cover the costs of diagnosis and treatment of a comprehensive and continuously updated list of conditions, designated in a schedule to the regulations as constituting prescribed minimum benefits that must be made available to all members of medical schemes and to their dependants. 22

The entitlements awarded by the Act and its regulations are operationalised by the creation of the Council for Medical Schemes, ${ }^{23}$ which oversees medical schemes' compliance with the Act and administers a detailed and efficient complaints mechanism, ${ }^{24}$ in terms of which members may, after having exhausted their schemes' internal dispute resolution processes, complain to the Council over, for instance, schemes' exclusion or restriction of membership, or their failure to cover prescribed minimum benefits. The Council may suspend the registration of medical schemes who fail to comply with the provisions of the Act or its regulations. ${ }^{25}$ The Council is further involved in making medical aid consumers aware of their rights and recourse in terms of the Act and the regulations. ${ }^{26}$

Overall, the Medical Schemes Act and its regulations have been credited for significantly broadening access to (mostly high-quality, private sector) medical care for members of medical schemes. ${ }^{27}$ But the Act's effectiveness in ensuring meaningful access to private health care services has been significantly hampered by the fact that it remains a lone island of translation of the right to access medical care in relation to the burgeoning South African private health sector. In particular, the almost complete lack of regulation of the South African private hospital and pharmaceutical industries has had the effect that, beyond prescribed minimum benefits, most forms of private

\footnotetext{
${ }^{21}$ Section 29(1)(s)-(t).

22 Section 29(1)(o) read with s 33(2)(a) and with regs 7-9 as well as Annexure A of the General Regulations Made in Terms of the Medical Schemes Act GN R 1262 of 20 October 1999. The regulations allow for limited conditions to apply to the enforcement of this entitlement, for instance by permitting medical schemes to insist on the use of particular treatment providers. For more detailed discussion of the provisions highlighted here, see Van Wyk C "Access to affordable HIV medicines in South Africa: Patents, parallel importation, generics and medical schemes" (2006) 39 De Jure 1, 21-22.

${ }^{23}$ Section 3 of Act 131 of 1998.

${ }^{24}$ Established and structured by ss 47-50.

${ }^{25}$ For an overview of the complaints process, see Hassim, Heywood \& Berger (fn 1 above) 273-74.

${ }^{26}$ See for instance the Council's detailed Consumer Education Manual - Medical Scheme Member Rights and Obligations (30 April 2002) available through http://www.medicalschemes.com (accessed 15 November 2010). The Council further runs a detailed and user-friendly website (ibid) which explains members' basic entitlements and allows for the online filing and tracking of complaints against medical schemes.
}

${ }^{27}$ Hassim, Heywood \& Berger (fn 1 above) 237. 
medical treatment have become unaffordable to all except the most well-off segments of society.

Apart from a highly publicised attempt to curb pharmaceutical profit margins, which stalled when the relevant price-control regulations were declared unconstitutional, ${ }^{28}$ there has been no legislative or executive action aimed at ensuring the accessibility, affordability or quality of private health care services. Moreover, it appears from the Supreme Court of Appeal judgment in Afrox Health Care $v$ Strydom ${ }^{29}$ that courts are loathe to define socio-economic obligations for the private health sector where these would interfere with freedom of contract. ${ }^{30}$ Absent statutorily or judicially defined entitlements, the extent to which consumers of private health services enjoy the right of access to health services is therefore dependent on their limited ability to assert the right within the confines of particular contractual relationships with private health service providers. ${ }^{31}$

Many South Africans are therefore, for the most part, left to exercise their right of access to health care services in the public health sector. Unfortunately, as will now be shown, translation of the right in the public sector has been uneven and unsatisfactory.

\subsection{Translation for the masses: The National Health Act and supporting policy}

For almost a decade after the adoption of the 1996 Constitution and the Department of Health's groundbreaking 1997 White Paper for the Transformation of the Health System of South Africa, the health system languished without framework legislation anchoring it in the constitutional dispensation. This severe (and arguably unconstitutional ${ }^{32}$ ) breakdown in translation finally abated with the coming into operation of significant portions of the National Health Act 61 of 2003 in May 2005. Yet approximately a third of the Act's provisions, many of which aim to operationalise its substantive provisions, remain unproclaimed at the time of writing. ${ }^{33}$

28 Department of Health Regulations Relating to a Transparent Pricing System for Medicines and Scheduled Substances GN R553 (30 April 2004), declared unconstitutional in Minister of Health v New Clicks South Africa 2006 (2) SA 311 (CC) for failing to set an appropriate dispensing fee that conformed to the rule of law and principles of administrative justice.

292002 (6) SA 621 (SCA).

30 For criticism of the Afrox decision in this context, see Pieterse M "Indirect horizontal application of the right to have access to health care services" (2007) 23 SAJHR 157, 176-177 and authorities cited there.

31 On the various factors that impact negatively on such contract-dependent enjoyment of the right, see Pieterse M “Relational socio-economic rights" (2009) 25 SAJHR 198, 201-02; 208-09.

32 See Pillay K "Tracking South Africa's progress on health care rights: Are we any closer to achieving the goal?" (2003) 7 Law, Democracy \& Development 55, 65; 78.

33 See also Gray A \& Jack C "Health legislation and policy" (2008) 13 SA Health Review 31, 33; 35; 45; 
This glaring translation failure notwithstanding, the provisions of the National Health Act present the most significant attempts at translation of the right to have access to health care services in the public sector to date. In terms of section 3(1)(e) the Minister of Health must, within available resources, "ensure the provision of such essential health services, which must at least include primary health services, to the population of the Republic as may be prescribed after consultation with the National Health Council". Then, section 4 of the Act determines:

"(1) The Minister, after consultation with the Minister of Finance, may prescribe conditions subject to which categories of persons are eligible for such free health services at public health establishments as may be prescribed.

(2) In prescribing any condition contemplated in subsection (1), the Minister must have regard to -

(a) the range of free health services currently available;

(b) the categories of persons already receiving free health services;

(c) the impact of any such conditions on access to health services; and

(d) the needs of vulnerable groups such as women, children, older persons and persons with disabilities.

(3) Subject to any condition prescribed by the Minister [of Health], the State and clinics and community health centres funded by the State must provide -

(a) pregnant and lactating women and children below the age of six years, who are not members or beneficiaries of medical aid schemes, with free health services;

(b) all persons, except members of medical aid schemes and their dependants and persons receiving compensation for compensable occupational diseases, with free primary health care services; and

(c) women, subject to the Choice on Termination of Pregnancy Act, 1996 ..., free termination of pregnancy services".

In terms of section 5, no one may be refused emergency medical treatment by public or private health care providers, workers or establishments. The Act further contains several provisions pertaining to the manner in which health care must be rendered, which flesh out patients' rights to autonomy and bodily integrity. ${ }^{34}$ Importantly, section 6 requires that patients be informed, in a language and manner that they can understand, of their health status and available treatment options. Moreover, section 12 mandates the wide dissemination of information on, among other things, the kinds of health services available; the extent of their availability; procedures through which available health services may be accessed; procedures for complaining about delivery of available services and the rights and obligations of patients. The establishment and

Hassim A; Heywood M \& Honermann B The National Health Act: A Guide (2008) xiii; xxi.

${ }^{34}$ Sections 6-8 of Act 61 of 2003. 
implementation of transparent, responsive and widely publicised complaints procedures is mandated by section 18 of the Act.

Unfortunately, further translation of these impressive provisions has thus far been woefully inadequate. In particular, definitions of concepts central to the enjoyment of these entitlements are vague or non-existent. The Act's definition of "health services", for instance, simply refers back to the relevant constitutional provisions, none of which provide any clarity on the content of the concept. More disabling has been the failure of various Ministers of Health to define the concepts "essential health services", "primary health care services" and "emergency medical services and treatment" by regulation, as required by the Act in order to enable the enforcement of the entitlements embodied by sections 3-5. Nor have any regulations been proclaimed that extend the availability of free health services or that prescribe any conditions for access thereto. Ironically, this latter failure has had the unintended positive consequence that those services listed in section 4(3) of the Act are currently available unconditionally. 35

When viewed together with the myriad non-operational provisions in the Act, it becomes clear that implementation of several entitlements embodied by the Act has been complicated significantly, if not rendered impossible, by translation failure. 36 The South African Human Rights Commission (SAHRC)'s observation that less than half of patients qualifying for free health services under section 4 of the Act actually receive them, testifies to the results of this failure. ${ }^{37}$

To be fair, the Department of Health has fairly extensively defined the notion of "primary health care" in its 1997 White Paper for the Transformation of the Health System of South Africa ${ }^{38}$ as well as in a subsequent policy document entitled The Primary Health Care Package for South Africa - a Set of Norms and Standards (2000). But since these are unenforceable policy documents, the definitions and standards that they contain do not assist in giving effect to the relevant rights embodied by the National Health Act in the same way that would have been the case if they were contained in regulations proclaimed in terms of the Act, which would be justiciable. ${ }^{39}$

A further policy document which significantly advances the translation of the right to have access to health care services is the Patients Rights Charter (2000) ("the PRC"), which predates the National Health Act but compliments its provisions. The PRC contains a comprehensively defined right of access to health care services, 40

\footnotetext{
${ }^{35}$ Hassim, Heywood \& Honermann (fn 33 above) 23 fn22.

36 Hassim, Heywood \& Berger (fn 1 above) 234; Hassim, Heywood \& Honermann (fn 33 above) xxi; 22fn21; 23fn22; SAHRC (fn 4 above) 6; 55-6;

${ }^{37}$ SAHRC (fn 4 above) 41.

${ }^{38}$ See specifically section 2.6 .2 of the White Paper.

${ }^{39}$ See Hassim, Heywood \& Berger (fn 1 above) 232; 234.

40 It provides as follows: "Everyone has the right of access to health care services that include: i. receiving timely emergency care at any health facility that is open regardless of one's ability to pay; ii.
} 
alongside rights, for instance, to a healthy and safe environment, to participation in health-related decision-making, to choice of health providers, to be referred for a second opinion, to continuity of care and to complain about health services. It is required for the PRC to be prominently displayed at health facilities, ${ }^{41}$ and complaints procedures regarding non-adherence to its provisions dovetail with those mandated by the National Health Act. The PRC has been credited for making the right of access to health care services more tangible for patients, although this has been curtailed by its limited reach (it applies only to patients who have been admitted to health care institutions and does not enable anyone to demand such admission), by the fact that it is not legally enforceable and by continued lack of awareness of its provisions. ${ }^{42}$

Further translation has been effected by policy documents such as the National Drugs Policy for South Africa (1996), which determines that drugs at primary health care level should be delivered free of charge and contains guidelines for the formulation of an Essential Drug List, ${ }^{43}$ as well as the Batho Pele principles of public service delivery. ${ }^{44}$ Like the PRC these have had a discernible impact in practice, but are not themselves legally enforceable and often require further translation. ${ }^{45}$

It is also worth mentioning that government has for several years toyed with the idea of introducing a National Health Insurance (NHI) policy in South Africa. Such a policy would dramatically alter the landscape of access to medical treatment, both by persons currently reliant on the public health sector and by persons who are currently enabled to access health care services in the private sector through private medical insurance. To the extent that the viability of a system of NHI will require the rationing of medical services, detailed translation of minimum entitlements to specific health services under such a system is arguably central to the endeavour. However,

treatment and rehabilitation that must be made known to the patient to enable the patient to understand such treatment or rehabilitation and the consequences thereof; iii. provision for special needs in the case of newborn infants, children, pregnant women, the aged, disabled persons, patients in pain, persons living with HIV or AIDS patients; iv. counseling without discrimination, coercion or violence on matters such as reproductive health, cancer or HIV/AIDS; v. palliative care that is affordable and effective in cases of incurable or terminal illness; vi. a positive disposition displayed by health care providers that demonstrate courtesy, human dignity, patience, empathy and tolerance; and vii. health information that includes the availability of health services and how best to use such services, and such information shall be in the language understood by the patient".

${ }^{41}$ Site visits by a researcher in September and October 2009 confirm general compliance with this requirement in public and private hospitals around Johannesburg.

42 Hassim, Heywood \& Berger (fn 1 above) 232; 247; 266-67; Ngwena C \& Cook R "Rights concerning health" in Brand D \& Heyns C (eds) Socio-economic Rights in South Africa (2005) 107, 145; Pillay (fn 32 above) 71; SAHRC (fn 4 above) 43.

${ }^{43}$ National Drugs Policy (1996) s 4.1; ch 5. Section 90(1)(d) of the National Health Act empowers the Minister of Health to make regulations pertaining to an essential drugs list. No such regulations have thus far been proclaimed.

${ }^{44}$ Published in terms of the White Paper on Transforming Public Service Delivery (GN 1459 of 1997).

45 For further comment on translation in terms of these instruments see Hassim, Heywood \& Berger (fn 1 above) 232; 234; 247; 266-67. 
despite much public rhetoric surrounding NHI and its ability to realise the right of access to medical treatment, 46 no formal draft policy has been forthcoming from the Department of Health as yet.

Overall, it appears that there has been significant translation of section 27 of the Constitution in relation to those South Africans who cannot afford to be members of medical aid schemes. However, such translation has for the most part been incomplete and, ironically, falls short of the degree of translation evident in relation to access to private medical care by beneficiaries of medical schemes. ${ }^{47}$ The result, as the following examples will show, is unequal implementation of translated entitlements and unequal enjoyment of constitutional rights.

\section{(a) Emergency Medical Treatment}

Section 27(3) of the Constitution, which determines that "no one may be refused emergency medical treatment", presents arguably the most direct and immediate entitlement to health care services to be found in the Constitution. However, it still requires further translation. First, it is necessary to formulate sufficiently generous and flexible, yet precise, definitions of "medical emergencies" and "emergency medical treatment" which will trigger the protection awarded by the provision. ${ }^{48}$ Secondly, the positive entitlements and obligations implied by the right need to be clearly circumscribed, so as to minimise the potentially devastating consequences of inconsistent implementation.

This is especially necessary in relation to emergency treatment by private health care providers, who are typically loath to provide services to patients who cannot guarantee payment. Whereas the so-called "horizontal" application of socio-economic rights against private entities is generally controversial, there is increasing acceptance that the right not to be refused emergency medical treatment does bind private health care providers.49 However, the extent of their constitutional obligations in this regard remains unclear. The need for these obligations to be legislatively clarified is underscored by section 8(3) of the Constitution, which indicates that the application of rights in the Bill of Rights against private entities should, in the first instance, be facilitated by legislation. Failing legislative translation,

46 For some of the relevant debates see, for instance, Shisana O "A national health system: Opportunities and challenges for South Africa" in Botha C \& Hendricks M (eds) Financing South Africa's National Health System through National Health Insurance (2008) 1,4; Broomberg J "Health reform must not destroy private sector" Cape Times (2 June 2009) 9; Van den Heever A "Insurance funding model doesn't fit our needs" Cape Times (9 June 2009) 9.

47 As also asserted in SAHRC (fn 4 above) 56.

48 See Pieterse $M$ "Enforcing the right not to be refused emergency medical treatment: Towards appropriate relief" (2007) 18 Stellenbosch LR 75, 81.

${ }^{49}$ See Currie I \& De Waal J The Bill of Rights Handbook (5ed 2005) 53; 593; Liebenberg S "South Africa's evolving jurisprudence on socio-economic rights: An effective tool in challenging poverty?" (2002) 6 Law, Democracy \& Development 159, 163; Pieterse (fn 30 above) 167-68; Pieterse (fn 48 above) 79-80 and authorities cited there. 
courts should attempt to give effect to the horizontal obligations implied by rights by applying or developing the common law..$^{50}$

Shortly after the coming into effect of the Constitution, the Constitutional Court was called upon to demarcate the application of section 27(3) as well as the extent of the positive obligations engendered thereby. Unfortunately, the facts of Soobramoney $v$ Minister of Health, KwaZulu Natal ${ }^{51}$ required the Court to approach this task negatively, since it had to justify why the right was not applicable in the circumstances. While the Court hence presented a fairly broad and flexible definition of medical emergencies as "sudden catastrophes" which "call for immediate attention",52 it was loath to impose positive obligations on the State. Accordingly, it gave an unduly restrictive interpretation of the reach of the provision, which it regarded as entailing only an entitlement not to be turned away by an open health facility which was able to render appropriate emergency treatment. ${ }^{53}$ The Court further declined to elaborate on any horizontal obligations imposed by the right.54 This clearly left the bulk of the translation exercise in relation to the reach of positive (public and private) obligations entailed by section 27(3) to the political branches.

Section 5 of the National Health Act determines that "a health care provider, health worker or health establishment may not refuse a person emergency medical treatment". Read together with the Act's definitions of "health worker", "health care provider" and "health establishment", it is clear that the obligations imposed by the provision are applicable to both public and private health care providers. However, "emergency medical treatment" is left undefined by the Act, section 1 of which merely regards "emergency medical treatment contemplated in section 27 of the Constitution" as falling within the Act's understanding of "health services". The Act then clearly extends a mandate of further translation to the Minister of Health, who is empowered to make regulations pertaining to emergency medical care.55 Lamentably, no such regulations have yet been forthcoming. 56

\footnotetext{
50 Pieterse (fn 30 above) 162-63. On the possible vindication of s 27(3) through the development of the common law, see Pieterse (fn 48 above) 85-9.

51 1998(1) SA 765 (CC).

52 Para 36; for discussion, see Pieterse (fn 48 above) 83 and authorities cited there.

53 Soobramoney para 20. For criticism see, for example, Brand D "The proceduralisation of South African socio-economic rights jurisprudence, or 'what are socio-economic rights for?"' in Botha H; Van der Walt A \& Van der Walt J Rights and Democracy in a Transformative Constitution (2003) 33, 47; Liebenberg (fn 49 above) 165; Pieterse (fn 48 above) 84-5; Scott C \& Alston P "Adjudicating constitutional priorities in a transnational context: A comment on Soobramoney's legacy and Grootboom's promise" (2000) 16 SAJHR 206, 247-48.

${ }^{54}$ Soobramoney paras 35; 48. See Pieterse (fn 48 above) 164-65.

${ }^{55}$ Section 90(1)(m) of Act 61 of 2003.

56 Draft regulations published in the Western Cape in 1999 did contain a definition of emergency care, but were never proclaimed.
} 
Instead, translation of section 27(3) has been scattered between several measures that apply in different contexts and are legally enforceable to differing degrees. Medical aid beneficiaries can obtain treatment for "emergency medical conditions", defined by the Regulations proclaimed in terms of the Medical Schemes Act as "the sudden and, at the time, unexpected onset of a health condition that requires immediate medical or surgical treatment, where failure to provide medical or surgical treatment would result in serious impairment to bodily functions or serious dysfunction of a bodily organ or part, or would place the person's life in serious jeopardy" ${ }^{57}$ as part of minimum prescribed benefits. In terms of the PRC, the right of access to health care services includes "receiving timely emergency care at any health care facility that is open regardless of one's ability to pay". Item 3(b) of the Schedule to the Promotion of Equality and Prevention of Unfair Discrimination Act 4 of 2000 further prohibits the discriminatory refusal of emergency medical treatment. 58 Finally, in response to inconsistent practices by its members, the Hospital Association of South Africa has published a draft code of ethics for private hospitals which defines "emergency medical treatment" as treatment necessary to stabilise an emergency medical condition ${ }^{59}$ and ethically obliges private hospitals to render such treatment without discrimination to patients who present themselves at emergency facilities, subject to reasonable subsequent compensation.60 This (significantly limited) horizontal obligation is clearly not legally enforceable in its current form.

The scattered, often unenforceable and clearly incomplete translation of the horizontal dimensions and positive obligations inherent to the right not to be refused emergency medical treatment has led to significant inconsistencies in compliance therewith, especially in the private health sector. ${ }^{61}$ The lacunae left by the current legislative and regulatory framework enable health providers to restrictively selfdefine their horizontal obligations in terms of the right and vest no clearly enforceable entitlements in patients. The SAHRC has accordingly urged further translation of the right, warning that "[u]nless there are transparent policies to guide [emergency] services that will and will not be provided, unequal distribution,

\footnotetext{
${ }^{57}$ Reg 7 of GNR 1262 of 20 Oct 1999.

58 On the extent of translation of s 27(3) effected by the totality of these measures, see Hassim, Heywood \& Berger (fn 1 above) 233.

${ }^{59}$ Clause 1 of the Proposed Code of Ethics for Private Hospitals - Hospital Association of South Africa (HASA) Private Hospital Review 2008: Examination of Factors Impacting on Private Hospitals (2008) 67, which further defines "emergency medical condition" as meaning " $(\mathrm{A})$ a medical condition manifesting itself by acute symptoms of sufficient severity (including severe pain) such that the absence of immediate medical attention could reasonably be expected to result in - (i) placing the health of the individual (or, with respect to a pregnant woman, the health of the woman or her unborn child) in serious jeopardy, (ii) serious impairment to bodily functions, (iii) serious dysfunction of any bodily organ or part; or (B) with respect to a pregnant woman who is having contractions; (i) that there is inadequate time to effect a safe transfer to another hospital before delivery, or (ii) that transfer may pose a threat to the health or safety of the woman or the unborn child".

60 Ibid clause 5; HASA (fn 59 above) 69.

${ }^{61}$ Hassim, Heywood \& Honermann (fn 33 above) xv; SAHRC (fn 4 above) 56.
} 
constituting a perverse form of rationing and an unequal access to and fulfilment of human rights will result by default, or omission, as is presently the case".62

\section{(b) Access to termination of pregnancy services}

Reproductive health care services are explicitly included in the ambit of section $27(1)(a)$ of the Constitution. In relation to abortion, significant and meaningful translation of the right to have access to such services took place in terms of the Choice on Termination of Pregnancy Act 92 of 1996, sections 2-5 of which clearly set out the circumstances in which women may request to have pregnancies terminated as well as the requirements that must be fulfilled when termination services are rendered.63 Moreover, section $4(3)(c)$ of the National Health Act determines that women should be able to access termination of pregnancy services in the public health sector free of charge.

But despite this clearly defined and circumscribed entitlement, there are several reports of inadequate enjoyment of this right. This is almost entirely ascribed to problems of implementation - several studies show low awareness, especially among rural women, of the extent of their entitlements in terms of these provisions, ${ }^{64}$ whereas the SAHRC reports that only about $50 \%$ of designated health facilities are currently offering abortion services. 65 This latter failure, in turn, is ascribed in part to a lack of suitably qualified health practitioners in the public health system and in part to the refusal by many health care practitioners, for reasons of conscience, to perform terminations. ${ }^{66}$

But both these seemingly logistical factors may at least partly be related to problems of translation. For instance, it may be argued that human resource capacity constraints in this context have been worsened by the Department of Health's failure to produce regulations pertaining to human resources under section 52 of the National Health Act ${ }^{67}$ as well as by restrictions in the Choice on Termination of Pregnancy Act on the circumstances in which registered midwives and nurses may assist in performing terminations. ${ }^{68}$ More pertinently, the Choice on Termination of Pregnancy Act's silence on the issue of conscientious objection to abortion creates

62 SAHRC (fn 4 above) 56.

63 For discussion, see Ngwena C "Accessing abortion services under the Choice on Termination of Pregnancy Act: Realising substantive equality" (2000) 25(3) Journal for Juridical Science 19, 32.

64 Gray \& Jack (fn 33 above) 39; Ngwena (fn 63 above) 33.

65 SAHRC (fn 4 above) 48. See also Pillay (fn 32 above) 76.

66 SAHRC (fn 4 above) 48.

67 See Hassim, Heywood \& Honermann (fn 33 above) 73.

68 In terms of s 2(2) of Act 92 of 1996, terminations may be performed only by registered medical practitioners and, in limited circumstances, by registered midwives. Current draft legislation aims to extend midwives' ability to perform terminations and to also allow registered nurses to assist with certain terminations. 
significant ambiguity over the circumstances under which medical professionals may refuse to perform terminations. ${ }^{69}$ This, in turn, leads to inconsistent practices which, especially in rural areas, often boil down to de facto denial of access. ${ }^{70}$

This goes to show that, even in relation to clearly defined legislative entitlements, translation breakdowns may nevertheless occur where legislation or policy inadequately define the scope of obligations incurred by obligation-bearers. This in turn indicates that increased attention should be paid to the translation of horizontal obligations incurred in terms of socio-economic rights.

\section{(c) Access to health services by foreign nationals}

The constitutional rights of access to health care services and emergency medical treatment are afforded to "everyone". This implies that criteria such as citizenship may not pose barriers to access, unless such barriers may be justified in terms of the general limitations clause in section 36 of the Constitution. ${ }^{71}$

However, statutory or policy-based elaboration of the right of access to health care services are silent on this aspect of the right, with neither the National Health Act, the Patients Rights Charter or any other official policy document containing provisions pertaining to access to treatment by non-nationals. Instead, the rights of foreigners are spelt out in, respectively, an internal memorandum and a directive by the National Department of Health, both of which determine that public hospitals may not insist on possession of national identity documentation as prerequisite for access to specific kinds of medical treatment, notably antiretroviral and emergency treatment.72 However, implementation of these directives varies drastically from hospital to hospital, with several hospitals insisting on presentation of South African identity documentation as an absolute requirement for access. ${ }^{73}$

${ }^{69}$ The determination in s 6 of Act 92 of 1996 that women who request termination services should be informed of their rights in terms of the Act does impose limited restrictions on rights of conscientious objection.

${ }^{70}$ For discussion, see Ngwena (fn 63 above) 39; Ngwena C "Conscientious objection and legal abortion in South Africa: Delineating the parameters" (2003) 28(1) Journal for Juridical Science 1, 4; 9-13; 16.

${ }^{71}$ See Pieterse M "Foreigners and socio-economic rights: Legal entitlements or wishful thinking?" (2000) 63 THRHR 51, 54-6.

72 Department of Health Memo: Access to Comprehensive HIV and AIDS Care, including Antiretroviral Treatment (2006) and Department of Health Revenue Directive: Refugees / Asylum Seekers with or without Permit BI 4/29 REFUG/ASYL 8 (2007), cited and discussed by Veary J "Migration, access to ART and survivalist livelihood strategies in Johannesburg" (2008) 7(3) African Journal of AIDS Research 361, 368-73.

73 SAHRC (fn 4 above) 53; Veary (fn 72 above) 367-69. All public hospitals in Gauteng require presentation of identity documentation upon seeking admission, yet only certain hospitals refuse admission or treatment to foreigners who are unable to present such documentation. See for instance the admission requirements of the Johannesburg Academic Hospital, available online through http://www.johannesburghospital.org.za (accessed 15 November 2010). 
Foreigners therefore enjoy severely unequal access to services which, by Departmental directive, they should be entitled to access. This is at least partly ascribable to the obscure nature and lack of legal status of the relevant directives and to the fact that they do not clearly provide for individual entitlements and obligations, or for means through which to insist on compliance with these.

\subsection{Analysis}

It appears that the current state of legislative and executive translation of section 27 of the Constitution is, at best, incomplete. In many instances the legislation or policy required to realise particular aspects of the right has simply not been drafted or proclaimed. In other cases, key concepts in legislation and policy have either been left undefined or have been defined vaguely and generally. Moreover, entitlements and corresponding obligations tend to be contained in documents that are obscure, lack official status, are not in final form or are not legally enforceable outside of the processes for which they themselves explicitly make allowance.

The result is that entitlements to particular forms of medical treatment either do not exist, or do exist but cannot be implemented because they are not justiciable or because measures to operationalise them have not been devised or finalised, or do exist and can be enforced but are haphazardly and inconsistently implemented. In the latter case, this is often because the obscurity, vagueness or inherent contradictions to entitlements or obligations lead to incomplete awareness thereof or to unwillingness of obligation-bearers to comply therewith; ${ }^{74}$ or enable duty-holders to deny or challenge the validity or enforceability of obligations; 75 or create space for unguided bureaucratic discretion which leads to inconsistent or unequal implementation. ${ }^{76}$

\section{JUDICIAL REVIEW OF TRANSLATION BREAKDOWN}

It has been argued that courts in a constitutional dispensation that incorporates rights-based judicial review of state action are well-placed to identify translation failures in relation to socio-economic rights, as well as the reasons for such failures, and to insist on their correction. ${ }^{77}$ In particular, the South African Constitutional Court's approach to socio-economic rights adjudication has received some praise for

\footnotetext{
74 Shown by Veary (fn 72 above) 371 in relation to access to antiretroviral treatment by foreigners.

75 Gray \& Jack (fn 33 above) 45. This was, for instance, the case with regulations aimed at reducing medicine prices by capping pharmaceutical profit margins, where poor drafting and inadequate consultation of stakeholders resulted in a successful challenge to the regulations (see Minister of Health $v$ New Clicks South Africa (fn 28 above) paras 13 (per the Court); 20; 233 (per Chaskalson CJ); 822; 835 (per Yacoob J)) and led to as yet indefinite delay in their implementation.

${ }^{76}$ See Williams (fn 9 above) 454-55.

77 Dixon (fn 15 above) 405.
} 
the manner in which it leaves the bulk of socio-economic rights-translation to the legislative and executive branches, while ensuring that legislative or executive translations are constitutionally compliant. ${ }^{78}$

In Government of the RSA v Grootboom ${ }^{79}$ the Constitutional Court introduced the standard of "reasonableness" for review, which it regards as appropriate to test legislation aimed at achieving the progressive realisation of socio-economic rights for constitutional compliance. The standard posits several requirements for legislative and executive translation. According to the Court, measures aimed at the progressive realisation of socio-economic rights have to be reasonable "both in their conception and their implementation".80 This means that measures have to "clearly allocate responsibilities and tasks to the different spheres of government and ensure that the appropriate financial and human resources are available [for the implementation of the right]",81 and that legislative measures have to be "supported by appropriate, welldirected policies and programmes implemented by the Executive".82 Measures further have to be balanced, flexible and inclusive, and have to cater for short, medium and long-term needs, ${ }^{83}$ but especially for the needs of those "whose needs are most urgent and whose ability to enjoy all rights therefore is most in peril". ${ }^{84}$

The reasonableness standard was appropriated in relation to health policy in Minister of Health $v$ Treatment Action Campaign (TAC), 85 where State policy on the use of anti-retroviral medication to prevent mother-to-child-transmission of HIV was challenged. In addition to employing all elements of the reasonableness test devised in Grootboom, the TAC Court held that reasonableness also required socio-economic policy to be transparent and to be communicated effectively to all concerned with its implementation:

"In order for it to be implemented optimally, a public health programme must be made known effectively to all concerned, down to the district nurse and patients. Indeed, for a public programme such as this to meet the constitutional requirement of reasonableness, its contents must be made known appropriately". ${ }^{86}$

The challenged policy was found to be unreasonable, primarily because of the rigid and seemingly arbitrary manner in which it restricted the availability of an essential drug to a limited number of designated sites, notwithstanding the need and capacity

${ }^{78}$ Liebenberg (fn 15 above) 319-20; Steinberg C "Can reasonableness protect the poor? A review of South Africa's socio-economic rights jurisprudence" (2006) 123 SALJ 264, 276; 284.

792001 (1) SA 46 (CC).

80 Para 42.

81 Para 39.

82 Para 42.

83 Para 43.

84 Para 44.

852002 (5) SA 721 (CC).

86 Para 123. 
to broaden access. The State was accordingly ordered to remove restrictions on the availability of the drug and to "permit and facilitate the use of Nevirapine for the purpose of reducing the risk of mother to child transmission of HIV and to make it available for this purpose at hospitals and clinics when in the judgment of the attending medical practitioner ... this is medically indicated" ${ }^{87}$

The reasonableness approach is clearly useful for identifying and correcting flaws in the content of laws and policies aimed at translating socio-economic rights. ${ }^{88}$ By insisting on the rationality, coherence and flexibility of laws and policy, the reasonableness analysis is also indirectly capable of correcting blockages in translation processes. This is illustrated by the TAC case, which involved a challenge to the content of a policy formulated by an Executive seized by a political agenda of Aids denialism, which made effective translation of section 27(1)(a) of the Constitution in the area of HIV all but impossible. The Court's dismissal of the State's dissident-influenced "concerns" with extending the availability of Nevirapine in the course of its reasonableness analysis, and its insistence that the State move beyond the impasse and broaden access to the drug, played a significant role in removing this blockage. The judgment signalled an about-turn in the Executive's official response to the HIV pandemic and paved the way for the formulation and implementation of a farreaching policy enabling wide-scale access to anti-retroviral medication in the public health sector. ${ }^{89}$

However, due to the focus of the reasonableness approach on the content of laws and policies, it is less clear whether it can perceive and correct translation failures where these result from the failure to pass laws or policies in the first place. Karrisha Pillay has argued that the failure to operationalise legislative provisions by proclaiming relevant regulations (such as that which currently impedes the implementation of much of the National Health Act) falls foul of the insistence of the reasonableness standard that legislative measures be supported by appropriate executive programmes and policies. ${ }^{90}$ The transparency standard inherent to the reasonableness approach may further be useful in countering translation failures occasioned by obscure and inadequately communicated policies (such as the directives on access to anti-retroviral medication by non-citizens). But where translation failures result from ambiguity created by legislative silences (such as that in relation to positive obligations imposed by the right not to be refused emergency medical treatment or the parameters of conscientious objection to terminations of pregnancy), reasonableness is likely to be of limited use.

\footnotetext{
87 Para 135.

88 Liebenberg (fn 15 above) 319-20.

${ }^{89}$ For further discussion, see Pieterse M "Health, social movements and rights-based litigation in South Africa" (2008) 35 Journal of Law \& Society 364, 384 and authorities cited there.

90 Pillay (fn 32 above) 73; 78.
} 
The reason for this is the widely lamented failure of the reasonableness analysis to engage with the content of constitutional rights (as opposed to the content of measures aimed at giving effect to them). Without being grounded in a substantive understanding of the rights that legislation or policy aims to translate, it is not possible for a reasonableness inquiry to identify untranslated aspects of the rights and to insist that translation takes place. This has the effect that only those aspects of socio-economic rights that the legislature or executive are willing to translate are realised.91 For this reason, several scholars have advocated a more substantive reasonableness analysis which involves judicial elaboration of, or engagement with, the content of rights and the entitlements that they engender. ${ }^{92}$

\section{CONCLUSION}

"It appears that little specific definition has been given to the right to health care and there is a need to clarify and further define what it means in practice and to people's everyday lives. This requires specification of the minimum levels of service required to ensure appropriate access to health care, which is unavailable for the public sector although the prescribed minimum benefits package exists for the private sector."93

This article has shown that unequal enjoyment of the right to have access to health care services results not only from inadequate implementation of legislative and policy measures, but may also be ascribed to failures to translate the right into claimable individual entitlements. While capacity and resource constraints present real hurdles to the implementation of constitutional rights, these are significantly compounded where individual entitlements and corresponding obligations have been inadequately defined and/or broadcast.

The article has presented several examples of such translation failures in current South African health law and policy. Not coincidentally, these are most acute in relation to the sector of the community whose enjoyment of socio-economic rights is most limited. Unless the right of access to health care services is to remain a pipe

\footnotetext{
${ }^{91}$ For a recent illustration of this in a different context, see Nokotyana $v$ Ekurhuleni Metropolitan Municipality 2010 (4) BCLR 312 (CC) paras 47-9, where the Constitutional Court declined to decide whether the right of access to adequate housing in s 26 of the Constitution included entitlements to sanitation or lighting. Instead, it decided the applicants' claim to be provided with sanitation and lighting in terms of chapters 12 and 13 of the National Housing Code (which was enacted, inter alia, to regulate the provision of such services) and held that they were not entitled to the services in terms of either, since neither applied to the situation in which the applicants found themselves. Since the applicants did not challenge the provisions of the Code as being inconsistent with the Constitution, this was held to exhaust their claim.

92 See for instance Brand (fn 53 above) 37; 53-4; Liebenberg (fn 5 above) 31-3; Liebenberg (fn 15 above) 321; Pieterse (2006) (fn 1 above) 487 and authorities cited there; Pieterse (2008) (fn 1 above) 342.

93 SAHRC (fn 4 above) 56.
} 
dream for the majority of South Africans, the legislature and executive must urgently endeavour to correct these failures.

Moreover, courts' current approach to socio-economic rights adjudication appears incapable of perceiving and correcting at least some forms of translation failure. While their reluctance to dictate translation processes is understandable, it is clearly necessary for courts to engage more robustly with legislative and executive efforts to give meaning to rights. 


\section{BIBLIOGRAPHY}

\section{Books}

Currie I \& De Waal J The Bill of Rights Handbook (5ed 2005).

Fraser N Unruly Practices: Power, Discourse and Gender in Contemporary Social Theory (1989).

Hassim A; Heywood M \& Berger J (eds) Health and Democracy (2007).

Hassim A; Heywood M \& Honermann B The National Health Act: A Guide (2008).

\section{Chapters in Books}

Brand D "The proceduralisation of South African socio-economic rights jurisprudence, or 'what are socio-economic rights for?"' in Botha H; Van der Walt A \& Van der Walt J Rights and Democracy in a Transformative Constitution (2003) 33-56.

Brand D "Introduction to socio-economic rights in the South African Constitution" in Brand D \& Heyns C (eds) Socio-economic Rights in South Africa (2005) 1-56.

Liebenberg S "Socio-economic rights: revisiting the Reasonableness review / minimum core debate" in Woolman S \& Bishop M (eds) Constitutional Conversations (2008) 303-329.

Ngwena C \& Cook R "Rights concerning health" in Brand D \& Heyns C (eds) Socioeconomic Rights in South Africa (2005) 107-151.

Pieterse M “On 'dialogue', 'translation' and 'voice': A reply to Sandra Liebenberg" in Woolman S \& Bishop M (eds) Constitutional Conversations (2008) 331-347.

Shisana 0 "A national health system: Opportunities and challenges for South Africa" in Botha C \& Hendricks M (eds) Financing South Africa's National Health System through National Health Insurance (2008) 1-6.

\section{Articles}

Dixon R "Creating dialogue about socio-economic rights: Strong-form versus weakform judicial review revisited" (2007) 5(3) Int. J of Constitutional Law 391-418.

Gray A \& Jack C "Health legislation and policy” (2008) 13 SA Health Review 31-49.

Liebenberg S "South Africa's evolving jurisprudence on socio-economic rights: An effective tool in challenging poverty?" (2002) 6 Law, Democracy \& Development 159-191.

Liebenberg S "Needs, rights and transformation: Adjudicating social rights” (2006) 17 Stellenbosch LR 5-36. 
Martin P "Just administrative action: The key to accessing socio-economic rights" (1999) 2(1) ESR Review 9-11.

Mubangizi JC "Protection of human rights in South Africa: Public awareness and perceptions" (2004) 29 Journal of Juridical Science 62-87.

Ngwena C "Accessing abortion services under the Choice on Termination of Pregnancy Act: Realising substantive equality" (2000) 25(3) Journal for Juridical Science 19-42.

Ngwena C "Conscientious objection and legal abortion in South Africa: Delineating the parameters" (2003) 28(1) Journal for Juridical Science 1-18.

Pieterse M "Foreigners and socio-economic rights: Legal entitlements or wishful thinking?" (2000) 63 THRHR 51-61.

Pieterse M "Coming to terms with judicial enforcement of socio-economic rights" (2004) 20 SAJHR 383-417.

Pieterse M "Resuscitating socio-economic rights: Constitutional entitlements to health care services" (2006) 22 SAJHR 473-502.

Pieterse $M$ "Enforcing the right not to be refused emergency medical treatment: Towards appropriate relief" (2007) 18 Stellenbosch LR 75-90.

Pieterse $M$ "Indirect horizontal application of the right to have access to health care services" (2007) 23 SAJHR 157-179.

Pieterse M "Health, social movements and rights-based litigation in South Africa" (2008) 35 Journal of Law \& Society 364-388.

Pieterse M “Relational socio-economic rights” (2009) 25 SAJHR 198-217.

Pillay K “Tracking South Africa's progress on health care rights: Are we any closer to achieving the goal?" (2003) 7 Law, Democracy \& Development 55-81.

Scott C \& Alston P "Adjudicating constitutional priorities in a transnational context: A comment on Soobramoney's legacy and Grootboom's promise" (2000) 16 SAJHR 206-268.

Steinberg C "Can reasonableness protect the poor? A review of South Africa's socioeconomic rights jurisprudence" (2006) 123 SALJ 264-284.

Van Wyk C "Access to affordable HIV medicines in South Africa: Patents, parallel importation, generics and medical schemes" (2006) 39 De Jure 1-24.

Veary J "Migration, access to ART and survivalist livelihood strategies in Johannesburg" (2008) 7(3) African Journal of AIDS Research 361-374.

Viljoen F "National legislation as a source of justiciable socio-economic rights" (2005) 6(3) ESR Review 6-9. 
Williams LA "Issues and challenges in addressing poverty and legal rights: A comparative United States / South African analysis" (2005) 21 SAJHR 436-472.

\section{Cases}

Afrox Health Care v Strydom 2002 (6) SA 621 (SCA).

Government of the RSA v Grootboom 2001 (1) SA 46 (CC).

Minister of Health v New Clicks South Africa 2006 (3) SA 247 (CC).

Minister of Health $v$ Treatment Action Campaign 2002 (5) SA 721 (CC).

Nokotyana v Ekurhuleni Metropolitan Municipality 2010 (4) BCLR 312 (CC).

Soobramoney v Minister of Health, KwaZulu Natal 1998 (1) SA 765 (CC).

\section{Legislation}

Choice on Termination of Pregnancy Act 92 of 1996.

Constitution of the Republic of South Africa, 1996.

Medical Schemes Act 131 of 1998.

National Health Act 61 of 2003.

\section{Regulations and Policy Documents}

Department of Health Regulations Relating to a Transparent Pricing System for Medicines and Scheduled Substances GN R 533 (30 April 2004).

Department of Health White Paper for the Transformation of the Health System of South Africa (1997).

General Regulations Made in Terms of the Medical Schemes Act GN R 1262 (20 October 1999).

National Drugs Policy (1996).

Patients' Rights Charter (2000).

\section{Other}

Broomberg J "Health reform must not destroy private sector" Cape Times (2 June 2009) 9. 
Hospital Association of South Africa (HASA) Private Hospital Review 2008: Examination of Factors Impacting on Private Hospitals (2008).

South African Human Rights Commission (SAHRC) Report Public Inquiry: Access to Health Care Services (2008).

Van den Heever A "Insurance funding model doesn't fit our needs" Cape Times (9 June 2009) 9. 